Bangladesh J. Bot. 44(4): 571-579, 2015 (December)

\title{
EVALUATION OF NOVEL BIO-FRIENDLY TWO-STEP PROCESS IN THE REMOVAL OF HEAVY METALS FROM THE WASTEWATER
}

\author{
Md Abdus Sobahan, Mir Sujaul Islam*, Rosli Mohd Yunus ${ }^{1}$ \\ AND Md ABdul Karim ${ }^{2}$ \\ Faculty of Civil Engineering and Earth Resources, University Malaysia Pahang, \\ Lebuhraya Tun Razak, 26300 Gambang Kuantan, Pahang, Malaysia
}

Key words: Wastewater, Bioremediation, Heavy metals

\begin{abstract}
Two-step treatment technique was developed for the treatment of water by Pseudomonas aeroginosa in a bioreactor in a first phase and then the bacterial treated water was treated with the vetiver grass, cattails and water hyacinth in second phase. Two-step process of bioremediation of 13 days was found to be satisfactory for $\mathrm{As}, \mathrm{Ba}, \mathrm{Cd}, \mathrm{Co}, \mathrm{Cr}, \mathrm{Cu}, \mathrm{Hg}, \mathrm{Ni}, \mathrm{Pb}$ and $\mathrm{Zn}$ in compared to the direct treatments with vetiver grass, cattails and water hyacinth in 20 days. As the plants cannot work or tolerate the higher concentrations of heavy metals, so with the first step on an average $52.48 \%$ reduction of heavy metals were done within 5 days. It was observed that $100 \%$ removal of $\mathrm{Pb}$ was found by two-step process of Pseudomas aeroginosa with cattails and water hyacinth, respectively in 13 days, while $98.16 \%$ removal of $\mathrm{Pb}$ was found by direct plant treatment of water hyacinth in 20 days. It was clear that the two-step treatment for vetiver grass, cattails and water hyacinth were found as the most effective treatments.
\end{abstract}

\section{Introduction}

The unsustainable industrialization and the improper disposal of wastewater are the main cause behind the contamination of aquatic environment. The heavy metal, such as $\mathrm{Cd}, \mathrm{Cu}, \mathrm{Cr}, \mathrm{Fe}$ and Ni polutan from the industrial wastewater which enter into food chain and ultimately cause the threat for lives (Singare et al. 2011). The addition of different chemicals from various industries the characteristics of the wastewater turned into complex in nature (Kumar et al. 2008). It is reported that single step phenomenon is time consuming and it is not possible to eradicate the high levels of contaminants as well as it does not give the expected feedback. Biological treatment activities are regarded as the environment friendly methods in wastewater treatment (Lofrano et al. 2013). Bacteria could play an effective role in eradicating pollutants specially heavy metals from wastewater (Kumaran et al. 2013). Nowadays, plants are being used in wastewater treatment and environmental cleansing as the secondary treatment procedure. In addition, the contaminated soil, sediment and water can be decontaminated by phytoremediation activities (Kokyo et al. 2014). Vetiver grass has the large rooting system, rapid growth and has been showed capability in removing contaminants especially heavy metals (Roongtanakiat et al. 2007). Water hyacinth (Eichhornia crassipes) and Cattails (Typha latifolia) are regarded as the best species in industrial wastewater treatments (Sukumaran 2013). The objective of the study is to evaluate the efficiency of the two-step treatment process of removal of heavy metals from the wastewater.

\footnotetext{
*Author for correspondence: <sujaulbd@gmail.com>. ${ }^{1}$ Faculty of Chemical \& Natural Resources Engineering, University Malaysia Pahang, Lebuhraya Tun Razak, 26300 Gambang Kuantan, Pahang, Malaysia. ${ }^{2}$ Department of Botany, University of Dhaka, Dhaka-1000, Bangladesh.
} 


\section{Materials and Methods}

Water samples were collected in plastic container from Gebeng industrial area, Pahang and preserved at low temperature. The selected heavy metals such as $\mathrm{As}, \mathrm{Ba}, \mathrm{Cd}, \mathrm{Co}, \mathrm{Cr}, \mathrm{Cu}, \mathrm{Hg}, \mathrm{Pb}$, $\mathrm{Ni}$ and $\mathrm{Zn}$ were determined by AOAC (2006) method using Inductive Coupled Plasma (ICPMS) spectrometry, Agilent 7500 CX, USA). Pseudomonas aeroginosa was isolated and used for the treatment of the water in aerobic bioreactor for 5 days (first phase, Fig. 1). Bacteria were subcultured on LB agar medium and preserved at low temperature.

The bioreactor was comprised of one feed tank, one digestion tank and one collection tank. Fifteen liters sample water with $150 \mathrm{ml}$ bacterial culture $\left(3.15 \times 10^{6}\right.$ cells $\left./ \mathrm{ml}\right)$ and 1.5 liters LB broth were added in the bioreactor (Nanda et al. 2011). The substrates were stirred continuously by

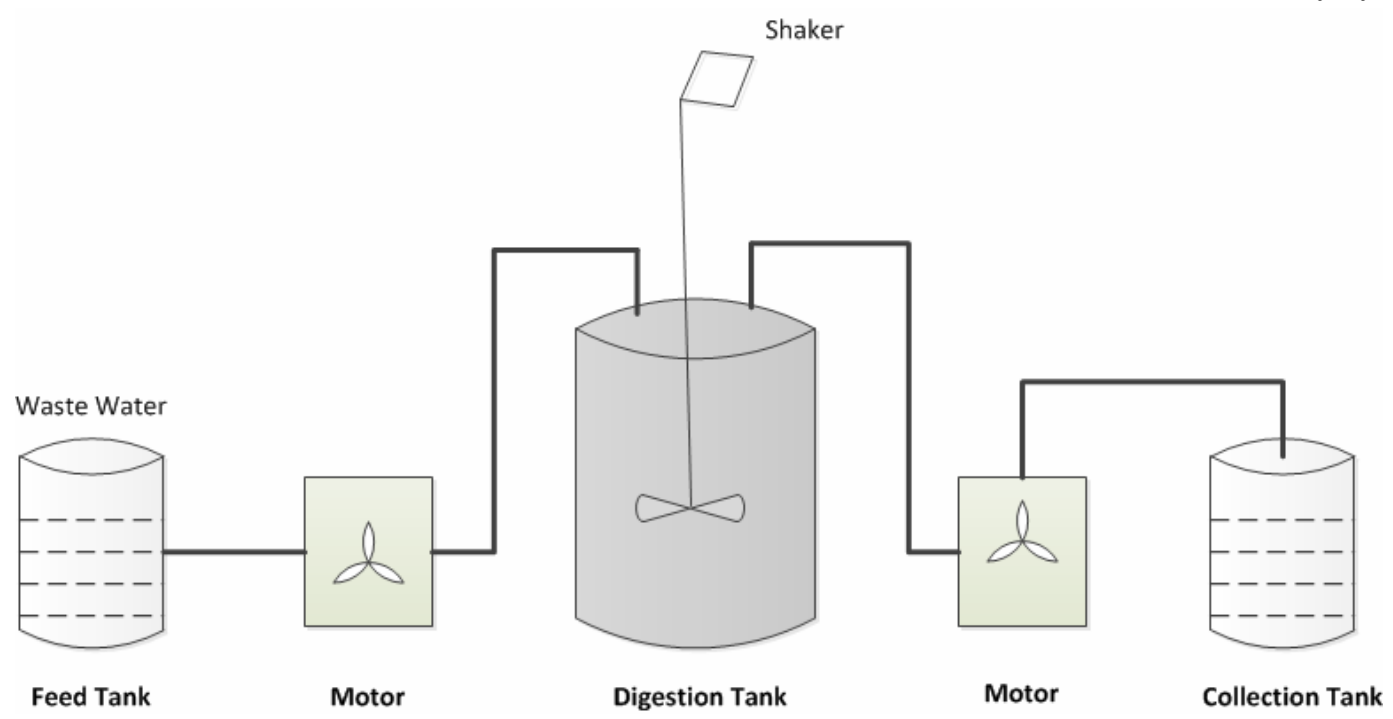

Fig. 1. Design of the aerobic bioreactor plant.

mechanical stirrer at $10 \mathrm{rpm}$ for proper mixing. A control was also made. The treated water was collected by ultra-centrifuge at 30,000 rpm for 20 minutes and heavy metals were measured.

In the experiment sample water was directly treated with vetiver grass (V1, V2, V3 and V4), cattails $(\mathrm{C} 1, \mathrm{C} 2, \mathrm{C} 3$, and $\mathrm{C} 4)$ and water hyacinth (WH1, WH2, WH3 and WH4) and conducted for 20 days, while bacterial treated water was also treated with those plants (V1, C1, and WH1) and conducted for 8 days (second phase, Table 1). Initially, all young plants were washed with tap and distilled water and then gently washed with fungicides (Comet M-45, class IV, conc. $2.5 \mathrm{~g} / \mathrm{l}$ ). Finally, all the saplings were kept into distilled water at 14 days for adaptation. Mixed fertilizer (NPK $21 \%$ of each, conc. $1.0 \mathrm{~g} / \mathrm{l}$ ) was added into each experimental pot with seven days interval. All experimental pots were kept under sunlight for $12 \mathrm{hrs} /$ day and the losses of wastewater were filled up with distilled water (Bharti and Banerjee 2012). During the experiment temperature and $\mathrm{pH}$ were maintained at 24.56 to $25.61^{\circ} \mathrm{C}$ and 7.45 to 7.94 , respectively. 
Table 1. Treatments of vetiver grass, cattails and water hyacinth.

\begin{tabular}{|c|c|}
\hline Treatments & Experimental design \\
\hline $\begin{array}{l}\text { Vetiver } \\
\text { grass }\end{array}$ & $\begin{array}{l}\mathrm{V} 1=\text { Bacterial treated water }(5 \text { days })+\text { fertilizer }+ \text { vetiver grass }(8 \text { days }) \\
\mathrm{V} 2=75 \% \text { wastewater }+ \text { fertilizer }+ \text { vetiver grass }(20 \text { days }) \\
V 3=100 \% \text { wastewater }+ \text { fertilizer }+ \text { vetiver grass }(20 \text { days }) \\
V 4=100 \% \text { wastewater }+ \text { vetiver grass }(20 \text { days })\end{array}$ \\
\hline Cattails & $\begin{array}{l}\mathrm{C} 1=\text { Bacterial treated water }(5 \text { days })+\text { fertilizer }+ \text { cattails }(8 \text { days }) \\
\mathrm{C} 2=75 \% \text { wastewater }+ \text { fertilizer }+ \text { cattails }(20 \text { days }) \\
\mathrm{C} 3=100 \% \text { wastewater }+ \text { fertilizer }+ \text { cattails }(20 \text { days }) \\
\mathrm{C} 4=100 \% \text { wastewater }+ \text { cattails }(20 \text { days })\end{array}$ \\
\hline $\begin{array}{l}\text { Water } \\
\text { hyacinth }\end{array}$ & $\begin{array}{l}\text { WH1 }=\text { Bacterial treated water }(5 \text { days })+\text { fertilizer }+ \text { water hyacinth }(8 \text { days }) \\
\text { WH } 2=75 \% \text { wastewater }+ \text { fertilizer }+ \text { water hyacinth }(20 \text { days }) \\
\text { WH3 }=100 \% \text { wastewater }+ \text { fertilizer }+ \text { water hyacinth }(20 \text { days }) \\
\text { WH4 }=100 \% \text { wastewater }+ \text { water hyacinth }(20 \text { days })\end{array}$ \\
\hline
\end{tabular}

Removal efficiencies were calculated based on the following formula (1) (Boonsong and Chansiri 2008).

$$
\% \text { Removal Efficiency } \frac{\mathrm{C}_{\mathrm{inp}}-\mathrm{C}_{\mathrm{tfp}}}{\mathrm{C}_{\mathrm{inp}}} \times 100
$$

where, $\mathrm{C}_{\text {inp }}$ is initial parameter concentration and $\mathrm{C}_{\mathrm{tfp}}$ is true final parameter concentration.

Kinetics of heavy metals removal were studied to develop a first order kinetic model and to determine kinetic constant (Pavlostathis et al. 1998).

$$
\operatorname{Ln}\left(\frac{\mathrm{C}_{0}}{\mathrm{C}}\right)=\mathrm{Kt}
$$

where, $\mathrm{K}$ is the constant rate for metal removal, $\mathrm{t}$ is time interval. $\mathrm{C}_{0}$ indicates concentration at initial days and $\mathrm{C}$ is concentration at final days.

SPSS version 20.0 was used to do the ANOVA test and the multiple comparisons (removal of metals by different treatments using Tukey (HSD)).

\section{Results and Discussion}

Maximum removal $(81.74 \%)$ of $\mathrm{Pb}$ was done by Pseudomonas aeruginosa, while minimum $(31.02 \%)$ was of Ba from the water sample (Table 2). The initial As content of the water was 0.05 $\mathrm{mg} / \mathrm{l}$, but after treatment it was changed to $0.02 \mathrm{mg} / \mathrm{l}$ and the reduction of As was $54.15 \%$. Nanda et al. (2011) exhibited that 34\% removal of As and 53\% removal of Co by Pseudomonas sp.; $44 \%$ of $\mathrm{Cd}$ and $34 \%$ of $\mathrm{Cu}$, respectively removed by Staphylococcus $\mathrm{sp}$. and $45 \% \mathrm{of} \mathrm{Hg}$ was removed by Bacillus sp. In the study we could reduce $57.06 \%$ of $\mathrm{Cd}, 81.74 \%$ of $\mathrm{Pb}, 53.16 \%$ of $\mathrm{Ni}, 51.72 \%$ of $\mathrm{Zn}, 35.03 \%$ of $\mathrm{Cu}$ and $54.01 \%$ of $\mathrm{Co}$ from the water sample, while Kumaran et al. (2013) observed $41 \%$ of $\mathrm{Cd}, 87.9 \%$ of $\mathrm{Pb}, 53 \%$ of $\mathrm{Ni}$ and $49.8 \%$ of $\mathrm{Zn}$ were removed by Pseudomonas sp. 
Table 2. Removal of heavy metals from water by Pseudomonas aeruginosa.

\begin{tabular}{ccccc}
\hline Metals & Initial $(\mathrm{mg} / \mathrm{l})$ & Final $(\mathrm{mg} / \mathrm{l})$ & Control $(\mathrm{mg} / \mathrm{l})$ & Removal $(\%)$ \\
\hline $\mathrm{As}$ & $0.05 \pm 0.0003$ & $0.02 \pm 0.0001$ & $0.05 \pm 0.0005$ & 54.15 \\
$\mathrm{Ba}$ & $0.06 \pm 0.0005$ & $0.03 \pm 0.0002$ & $0.05 \pm 0.0004$ & 31.02 \\
$\mathrm{Cd}$ & $0.10 \pm 0.0006$ & $0.04 \pm 0.0002$ & $0.09 \pm 0.0008$ & 57.06 \\
$\mathrm{Co}$ & $0.05 \pm 0.0007$ & $0.02 \pm 0.0003$ & $0.05 \pm 0.0003$ & 54.01 \\
$\mathrm{Cr}$ & $0.06 \pm 0.0006$ & $0.02 \pm 0.0002$ & $0.06 \pm 0.0005$ & 61.83 \\
$\mathrm{Cu}$ & $0.09 \pm 0.0005$ & $0.05 \pm 0.0001$ & $0.08 \pm 0.0004$ & 35.03 \\
$\mathrm{Hg}$ & $0.06 \pm 0.0005$ & $0.03 \pm 0.0002$ & $0.06 \pm 0.0006$ & 45.09 \\
$\mathrm{Ni}$ & $0.06 \pm 0.0006$ & $0.02 \pm 0.0001$ & $0.05 \pm 0.0003$ & 53.16 \\
$\mathrm{~Pb}$ & $0.07 \pm 0.0003$ & $0.01 \pm 0.0002$ & $0.07 \pm 0.0007$ & 81.74 \\
$\mathrm{Zn}$ & $0.08 \pm 0.0004$ & $0.03 \pm 0.0003$ & $0.07 \pm 0.0003$ & 51.72 \\
\hline
\end{tabular}

It was observed that Pseudomonas aeruginosa could remove at 6.05, 14.19, 21.81, 26.03 and $54.15 \%$ of As after 6, 12, 24, 48 and $120 \mathrm{hrs,} \mathrm{respectively} \mathrm{(Table} \mathrm{3).} \mathrm{The} \mathrm{same} \mathrm{reducing} \mathrm{trend} \mathrm{was}$ also seen with $\mathrm{Ba}, \mathrm{Cd}, \mathrm{Co}, \mathrm{Cr}, \mathrm{Cu}, \mathrm{Hg}, \mathrm{Ni}, \mathrm{Pb}$ and $\mathrm{Zn}$ after 6, 12, 24, 48 and $120 \mathrm{hrs}$, respectively (Table 3).

Table 3. Heavy metal removal (\%) by Pseudomonas aeruginosa.

\begin{tabular}{cccccc}
\hline Parameters & $6 \mathrm{hrs}$ & $12 \mathrm{hrs}$ & $24 \mathrm{hrs}$ & $48 \mathrm{hrs}$ & $120 \mathrm{hrs}$ \\
\hline $\mathrm{As}$ & 6.05 & 14.19 & 21.81 & 26.03 & 54.15 \\
$\mathrm{Ba}$ & 4.61 & 9.71 & 14.92 & 19.99 & 31.02 \\
$\mathrm{Cd}$ & 7.61 & 15.09 & 24.38 & 32.34 & 57.06 \\
$\mathrm{Co}$ & 9.02 & 13.03 & 21.66 & 30.83 & 54.01 \\
$\mathrm{Cr}$ & 13.71 & 25.96 & 37.20 & 44.37 & 61.83 \\
$\mathrm{Cu}$ & 5.02 & 11.39 & 17.63 & 21.55 & 35.03 \\
$\mathrm{Hg}$ & 6.01 & 12.93 & 17.52 & 24.16 & 45.09 \\
$\mathrm{Ni}$ & 10.82 & 17.94 & 24.71 & 37.04 & 53.16 \\
$\mathrm{~Pb}$ & 11.73 & 20.05 & 32.18 & 55.97 & 81.74 \\
$\mathrm{Zn}$ & 7.83 & 13.47 & 18.39 & 29.13 & 51.72 \\
\hline
\end{tabular}

Ajao et al. (2011) reported that Pseudomonas aeruginosa and Bacillus subtilis could remove $20.00,34.31,35.32$ and $22.95 \%$ of $\mathrm{Pb}, \mathrm{Cu}, \mathrm{Zn}$ and $\mathrm{Cr}$, respectively from textile effluent after 5 days and $48.00,60.77,85.07$ and $50.82 \%$ of $\mathrm{Pb}, \mathrm{Cu}, \mathrm{Zn}$ and $\mathrm{Cr}$, respectively after 10 days.

It is important the kinetics of heavy metal removal from wastewater in order to what type of metal removes faster or slower by bacterial treatment. So far, there are few reports on heavy metals removal kinetics. K value of heavy metals was ranked $\mathrm{Pb}>\mathrm{Cr}>\mathrm{Cd}>\mathrm{As}>\mathrm{Co}>\mathrm{Ni}>\mathrm{Zn}>$ $\mathrm{Hg}>\mathrm{Cu}>\mathrm{Ba}$ (Fig. 2). $\mathrm{Pb}$ was removed faster because the $\mathrm{K}$ value was higher than any other metals and followed by $\mathrm{Cr}$, $\mathrm{Cd}$ etc., while $\mathrm{K}$ value was found lower for $\mathrm{Ba}$, means $\mathrm{Ba}$ removed slowly. 
The satisfactory $\mathrm{R}^{2}$ values were found in all metals of the experiments which validate the data obtained in the study (Fig. 2).
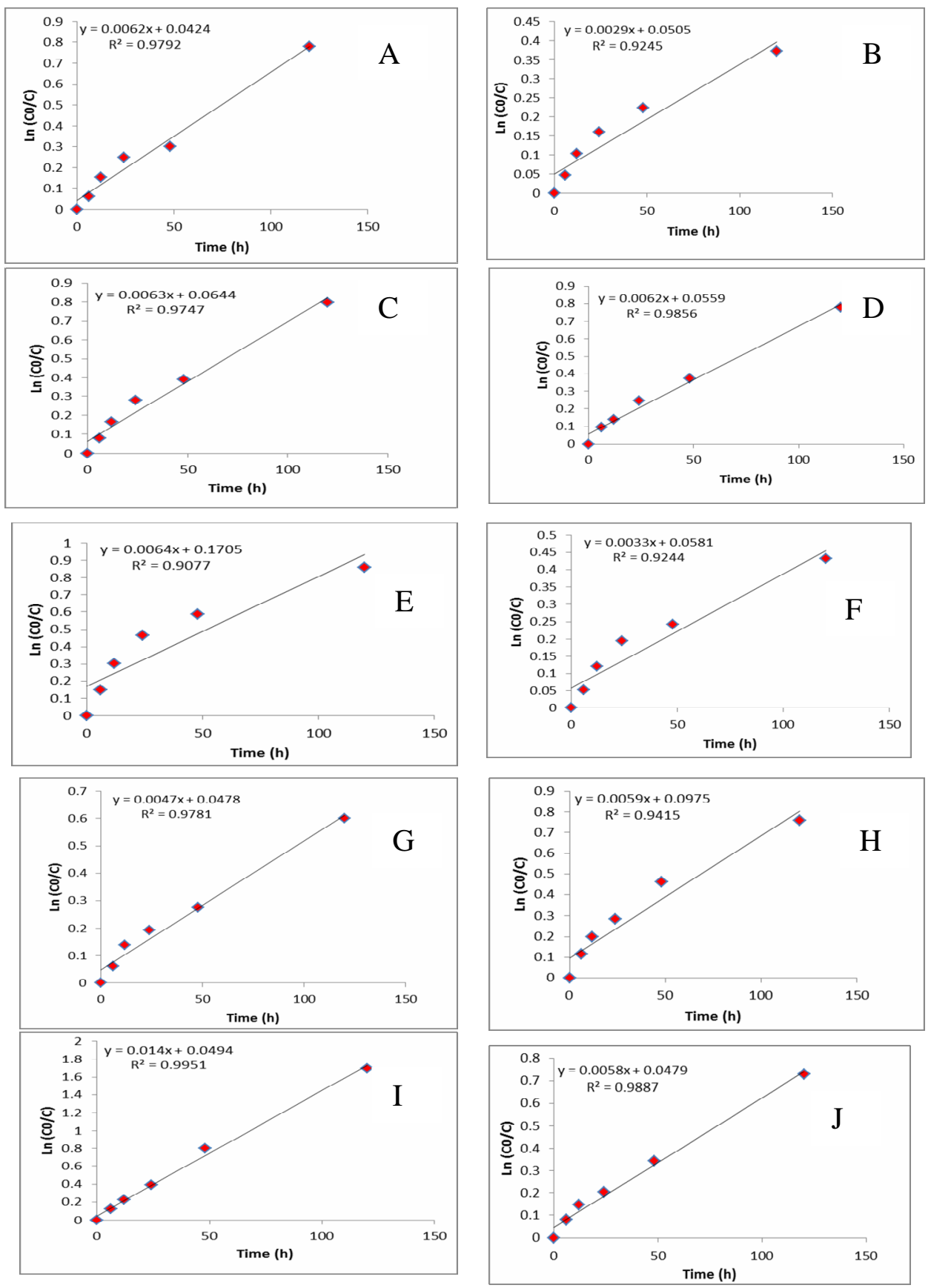

Fig. 2. Kinetics of heavy metals removal by Pseudomonas aeruginosa: (A) As, (B) Ba, (C) Cd, (D) $\mathrm{Co}$, (E) $\mathrm{Cr}$, (F) Cu, (G) $\mathrm{Hg}$, (H) Ni, (I) $\mathrm{Pb}$ and (J) Zn. 
Comparative heavy metal removal efficiency was shown in the Table 4. The removal efficiency of As was found $89.37 \%$ in two-step process with V1 after 13 days. On the other hand,

Table 4. Comparative efficiencies $(\%)$ between two steps process and the direct treatment.

\begin{tabular}{|c|c|c|c|c|c|}
\hline & \multirow[b]{2}{*}{ Metals } & \multicolumn{4}{|c|}{ Treatments } \\
\hline & & V1 & $\mathrm{V} 2$ & V3 & V4 \\
\hline \multirow{11}{*}{$\begin{array}{l}\text { Vetiver } \\
\text { grass }\end{array}$} & As & 89.37 & 79.58 & 0.00 & 0.00 \\
\hline & $\mathrm{Ba}$ & 80.16 & 79.06 & 0.00 & 0.00 \\
\hline & $\mathrm{Cd}$ & 95.62 & 91.32 & 0.00 & 0.00 \\
\hline & Co & 67.93 & 63.77 & 0.00 & 0.00 \\
\hline & $\mathrm{Cr}$ & 94.49 & 91.38 & 0.00 & 0.00 \\
\hline & $\mathrm{Cu}$ & 90.70 & 89.59 & 0.00 & 0.00 \\
\hline & $\mathrm{Hg}$ & 78.26 & 61.39 & 0.00 & 0.00 \\
\hline & $\mathrm{Ni}$ & 87.85 & 84.48 & 0.00 & 0.00 \\
\hline & $\mathrm{Pb}$ & 98.57 & 75.01 & 0.00 & 0.00 \\
\hline & $\mathrm{Zn}$ & 95.68 & 92.47 & 0.00 & 0.00 \\
\hline & & $\mathrm{C} 1$ & $\mathrm{C} 2$ & $\mathrm{C} 3$ & $\mathrm{C} 4$ \\
\hline \multirow{11}{*}{ Cattails } & As & 99.09 & 80.51 & 88.80 & 36.68 \\
\hline & $\mathrm{Ba}$ & 69.64 & 60.66 & 61.64 & 30.27 \\
\hline & $\mathrm{Cd}$ & 91.43 & 70.28 & 78.13 & 32.61 \\
\hline & Co & 81.92 & 61.68 & 72.08 & 31.54 \\
\hline & $\mathrm{Cr}$ & 92.67 & 82.26 & 90.61 & 27.59 \\
\hline & $\mathrm{Cu}$ & 81.69 & 65.39 & 77.42 & 18.83 \\
\hline & $\mathrm{Hg}$ & 83.17 & 68.39 & 73.64 & 29.88 \\
\hline & $\mathrm{Ni}$ & 80.45 & 70.83 & 76.06 & 20.36 \\
\hline & $\mathrm{Pb}$ & 100 & 70.00 & 78.25 & 22.48 \\
\hline & $\mathrm{Zn}$ & 99.22 & 96.96 & 97.81 & 33.51 \\
\hline & & WH1 & WH2 & WH3 & WH4 \\
\hline \multirow{10}{*}{$\begin{array}{l}\text { Water } \\
\text { hyacinth }\end{array}$} & As & 90.15 & 70.61 & 0.00 & 0.00 \\
\hline & $\mathrm{Ba}$ & 65.66 & 46.87 & 0.00 & 0.00 \\
\hline & $\mathrm{Cd}$ & 100 & 96.55 & 0.00 & 0.00 \\
\hline & Co & 77.73 & 69.91 & 0.00 & 0.00 \\
\hline & $\mathrm{Cr}$ & 90.66 & 87.18 & 0.00 & 0.00 \\
\hline & $\mathrm{Cu}$ & 82.81 & 79.22 & 0.00 & 0.00 \\
\hline & $\mathrm{Hg}$ & 93.28 & 79.30 & 0.00 & 0.00 \\
\hline & $\mathrm{Ni}$ & 76.27 & 69.93 & 0.00 & 0.00 \\
\hline & $\mathrm{Pb}$ & 100 & 98.16 & 0.00 & 0.00 \\
\hline & $\mathrm{Zn}$ & 91.72 & 89.98 & 0.00 & 0.00 \\
\hline
\end{tabular}


from the direct treatment with V2 showed $79.58 \%$, while V3 and V4 exhibited no removal due to higher concentrations and toxicity of As that killed the vetiver grass. In the study removal efficiency of As was higher in two step treatment process in comparison with the direct treatment by vetiver grass. The same trend was also observed with $\mathrm{Ba}, \mathrm{Cd}, \mathrm{Co}, \mathrm{Cr}, \mathrm{Cu}, \mathrm{Hg}, \mathrm{Ni}, \mathrm{Pb}$ and $\mathrm{Zn}$, respectively in two step processes. In case of cattails, the As removal by direct treatment was found $80.51 \%(\mathrm{C} 2), 88.80 \%$ (C3) and $36.68 \%$ (C4) after 20 days, respectively. It was observed that As reduction efficiency was increased with increasing the percentage of wastewater and addition of fertilizer as a source of nutrients and consisted with the $\mathrm{Ba}, \mathrm{Cd}, \mathrm{Co}, \mathrm{Cr}, \mathrm{Cu}, \mathrm{Hg}, \mathrm{Ni}, \mathrm{Pb}$ and $\mathrm{Zn}$. Kong et al. (2003) found that $13-58 \% \mathrm{Hg}$ removal with the pig farm wastewater by vetiver grass. However, combined treatment with Pseudomonas aeruginosa and cattails could remove $99.09 \%$ (C1) As after 13 days. Yang et al. (2006) reported 70.59\% $\mathrm{Hg}$ reductions by cattails. In experiment with water hyacinth, removal efficiency of As was found $90.15 \%$ by two step process and $70.61 \%$ after 20 days by direct treatment. So, two step processes combined with Pseudomonas aeruginosa and water hyacinth is more effective for the removal of As from the wastewater in comparison with direct treatment with water hyacinth that also followed the removal efficiency with $\mathrm{Ba}, \mathrm{Cd}, \mathrm{Co}, \mathrm{Cr}, \mathrm{Cu}, \mathrm{Hg}, \mathrm{Ni}, \mathrm{Pb}$ and $\mathrm{Zn}$. However, no removal was observed with WH3 and WH4 due to high concentration and toxicity of As that killed water hyacinth. Sukumaran (2013) reported that cattails can remove As approx. 87.00\% after 15 days, while water hyacinth can remove As about $66.08 \%$. Removal of $\mathrm{Zn}$ by water hyacinth was reported by Mishra and Trepathi (2009).

Table 5. ANOVA.

\begin{tabular}{llccccc}
\hline \multirow{2}{*}{ Removal } & $\begin{array}{c}\text { Sum of } \\
\text { squares }\end{array}$ & $\begin{array}{c}\text { Degree of } \\
\text { freedoms }\end{array}$ & $\begin{array}{c}\text { Mean } \\
\text { square }\end{array}$ & $\begin{array}{c}\text { F-test } \\
\text { value }\end{array}$ & $\begin{array}{c}\text { Significant } \\
(\%)\end{array}$ \\
\cline { 2 - 7 } & Between groups & 27184.40 & 7 & 3883.49 & 32.78 & 0.00 \\
& Within groups & 8529.60 & 72 & 118.47 & & \\
& Total & 35714.00 & 79 & & & \\
\multirow{2}{*}{ Metals } & Between groups & 0.00 & 7 & 0.00 & 0.00 & 1.00 \\
& Within groups & 660.00 & 72 & 9.17 & & \\
& Total & 660.00 & 79 & & & \\
\hline
\end{tabular}

The result exhibited that 98.57, 100 and $100 \% \mathrm{~Pb}$ was removed with $\mathrm{V} 1, \mathrm{C} 1$ and $\mathrm{WH} 1$, respectively, while $75.01,78.25$ and $98.16 \%$ with $\mathrm{V} 2, \mathrm{C} 3$ and $\mathrm{WH} 2$, respectively. Syukor et al. (2013) reported similar findings with cattails. Zn removal was observed 95.68, 99.22 and $91.72 \%$ with $\mathrm{V} 1, \mathrm{C} 1$ and $\mathrm{WH} 1$, while $92.47,97.81$ and $89.98 \%$ with $\mathrm{V} 2, \mathrm{C} 3$ and $\mathrm{WH} 2$, respectively.

From the Tables 5 and 6, it is clear that Null hypothesis is rejected here. In case of metal removal, as the $\mathrm{p}$ value $0.00(\mathrm{p}<0.05)$, so there is significance difference between groups and within groups (Table 5). In case of treatments, there are significant differences among treatments. For vetiver grass, V1 is the best treatment because the mean difference between V1 and V2 shows positive value, while the difference between V2 and V1 presents negative value (Table 6). So the treatment of two-step process for vetiver grass (V1) is the effective treatment.

For cattails, $\mathrm{C} 4$ is the least treatment, and $\mathrm{C} 1$ is the best treatment because the difference between $\mathrm{C} 1$ and $\mathrm{C} 4$ is high. Moreover, all difference values for $\mathrm{C} 1 \mathrm{C} 1$ and $\mathrm{C} 2, \mathrm{C} 1$ and $\mathrm{C} 3$, and $\mathrm{C} 1$ and $\mathrm{C} 4$ ) has been found positive. So, $\mathrm{C} 1$ is the best treatment among all cattails treatments. Furthermore, there is significant difference between $\mathrm{C} 1$ and $\mathrm{C} 4$ because the $\mathrm{p}$ value is $0.00(\mathrm{p}<$ 
0.05). For water hyacinth, there is positive difference between WH1 and WH2. Nevertheless, there is a negative difference value between $\mathrm{WH} 2$ and $\mathrm{WH} 1$. Therefore, WH1 is the best treatment.

Table 6. Multiple comparisons (Removal of metals by different treatments using Tukey HSD).

\begin{tabular}{|c|c|c|c|c|c|}
\hline \multirow[b]{2}{*}{ Treatments } & \multirow[b]{2}{*}{ Treatments } & \multirow[b]{2}{*}{ Difference } & \multirow[b]{2}{*}{$\begin{array}{c}\text { Significant } \\
(\%)\end{array}$} & \multicolumn{2}{|c|}{$95 \%$ confidence interval } \\
\hline & & & & Lower bound & Upper bound \\
\hline V1 & $\mathrm{V} 2$ & 7.06 & 0.83 & -8.14 & 22.25 \\
\hline \multirow[t]{2}{*}{$\mathrm{V} 2$} & V1 & -7.06 & 0.83 & -22.25 & 8.14 \\
\hline & $\mathrm{C} 2$ & $15.23^{*}$ & 0.05 & 0.04 & 30.43 \\
\hline \multirow[t]{3}{*}{$\mathrm{C} 1$} & $\mathrm{C} 3$ & 8.48 & 0.66 & -6.71 & 23.68 \\
\hline & $\mathrm{C} 4$ & $59.55^{*}$ & 0.00 & 44.36 & 74.75 \\
\hline & $\mathrm{C} 1$ & $-15.23^{*}$ & 0.05 & -30.42 & -0.04 \\
\hline \multirow[t]{3}{*}{$\mathrm{C} 2$} & $\mathrm{C} 3$ & -6.75 & 0.86 & -21.94 & 8.45 \\
\hline & $\mathrm{C} 4$ & $44.32^{*}$ & 0.00 & 29.12 & 59.52 \\
\hline & $\mathrm{C} 1$ & -8.48 & 0.66 & -23.68 & 6.71 \\
\hline \multirow[t]{3}{*}{$\mathrm{C} 3$} & $\mathrm{C} 2$ & 6.75 & 0.86 & -8.45 & 21.94 \\
\hline & $\mathrm{C} 4$ & $51.07^{*}$ & 0.00 & 35.87 & 66.27 \\
\hline & $\mathrm{C} 1$ & $-59.55^{*}$ & 0.00 & -74.75 & -44.36 \\
\hline \multirow[t]{2}{*}{$\mathrm{C} 4$} & $\mathrm{C} 2$ & $-44.32^{*}$ & 0.00 & -59.52 & -29.13 \\
\hline & $\mathrm{C} 3$ & $-51.07^{*}$ & 0.00 & -66.27 & -35.87 \\
\hline WH1 & WH2 & 8.06 & 0.72 & -7.14 & 23.25 \\
\hline WH2 & WH1 & -8.06 & 0.72 & -23.25 & 7.14 \\
\hline
\end{tabular}

Among three plants vetiver grass and water hyacinth were observed less tolerant compared to cattails. It is reported that almost all the plants can be used for secondary treatment. The two-step process was found more effective in removing heavy metals from the industrial wastewater compare to direct treatments with plants.

\section{Acknowledgement}

The authors are grateful to the Faculty of Civil Engineering \& Earth Resources (FKASA) of University Malaysia Pahang (UMP) as the research was financially assisted by the project RDU1203122 and GRS 130322.

\section{References}

Ajao AT, Adebayo GB and Yakubu SE 2011. Bioremediation of textile industrial effluent using mixed culture of Pseudomonas aeruginosa and Bacillus subtilis immobilized on agar agar in a Bioreactor. J. Microb. and Biotec. Res. 1: 50-56. 
AOAC 2006. Association of Official Analytical Chemists ( $18^{\text {th }}$ Ed.). The Scientific Association Dedicated to Analytical Excellence.

Bharti S and Banerjee TK 2012. Phytoremediation of coalmine effluent. Ecotoxic and Environ. Safety 81: 3642.

Boonsong K and Chansiri M 2008. Efficiency of vetiver grass (Vetiveria zizanioides (L.) Nash) cultivated with floating platform technique in domestic wastewater treatment. AU. J. T. 12(2): 73-80.

Kokyo O, Cao T, Li T and Cheng H 2014. Study on application of phytoremediation technology in management and remediation of contaminated soils. J. Clean Energy Technol. 2: 216-220.

Kong X, Lin W, Wang B and Luo F 2003. Study on vetiver's purification for wastewater from pig farm. Truong $\mathrm{P}$ and Hanping $\mathrm{X}$ (Eds.). In: Proceedings of the third international conference on vetiver and exhibition: vetiver and water; an eco-technology for water quality improvement, land stabilization and environmental enhancement. China agriculture press, Guangzhou, China. p. 170.

Kumar A, Yadav AK, Sreekrishnan TR, Satya S and Kaushik CP 2008. Treatment of low strength industrial cluster wastewater by anaerobic hybrid reactor. Bioresour. Technol. 99: 3123-3129.

Kumaran NS, Sundaramanickam A and Bragadeeswaran S 2013. Absorption studies on heavy metal by isolated bacterial strain (Pseudomonas sp.) from uppanar esturine water. South-East coast of India. J. Appl. Sci. in Environ. Sanit. 6: 471-476.

Lofrano G, Meriç S, Zengin GE and Orhon D 2013. Chemical and biological treatment technologies for leather tannery chemicals and wastewaters: A review. Sci. Total Environ. 461-462: 265-281.

Mishra VK and Tripathi BD 2009. Accumulation of chromium and zinc from aquous solutions using water hyacinth (Eichhornia crassipes). J. Hazard. Mater. 164(2-3): 1059-1063.

Nanda M, Sharma D and Kumar A 2011. Removal of heavy metals from industrial effluent using bacteria. Inter. J. Environ. Sci. 2(2): 781-787.

Pavlostathis SG, Miller TL and Wolin MJ 1998. Kinetics of insoluble cellulose fermentation by continuous cultures of Ruminococcus albus. Appl. and Environ. Microbiol. 54(11): 2660-2663.

Roongtanakiat N, Tangruangkiat S and Meesat R 2007. Utilization of vetiver grass (Vetiveria zizanioides) for removal of heavy metals from industrial wastewaters. Science Asia 33: 397-403.

Singare PU, Jagtap AG and Lokhande RS 2011. Water pollution by discharge effluents from Gove industrial area of Maharashtra, India: dispersion of heavy metals and their toxic effects. Int. J. Global Environ. Issues 11(1): 28-36.

Sukumaran D 2013. Phytoremediation of heavy metals from industrial effluent using constructed wetland technology. Appl. Ecol. Environ. Sci. 1(5): 92-97.

Syukor AAR, Zularisam AW, Idreis Z, Ismid MM, Suryati MS, Hasmainie AH and Thomas DL 2013. Potential of aquatic plants as phytoremediator for treatment of petrochemical wastewater in Gebeng area, Kuantan. Advances in Environ. Bio. 7: 3808-3814.

Yang B, Lan CY, Yang CS, Liao WB, Chang H and Shu WS 2006. Long-term efficiency and stability of wetlands for treating wastewater of a lead/zinc mine and the concurrent ecosystem development. Environ. Pollution 143: 499-512. 